Article

\title{
Optimization of the Technological Parameters for Obtaining Zn-Ti Based Composites to Increase the Performance of $\mathrm{H}_{2} \mathrm{~S}$ Removal from Syngas
}

\author{
Annette Madelene Dăncilă ${ }^{1}$, Simona Căprărescu ${ }^{1}$, Constantin Bobirică ${ }^{1}$, Violeta Purcar ${ }^{2}$, \\ Gabriel Gârleanu ${ }^{3}{ }^{(0)}$, Eugeniu Vasile ${ }^{4}$, Cristina Modrogan ${ }^{1, *}$, Claudia Borda ${ }^{3}$ and \\ Dan Dobrotǎ ${ }^{5, * \mathbb{D}}$
}

1 Faculty of Applied Chemistry and Materials Science, University POLITEHNICA of Bucharest, Polizu 1-7, RO-060042 Bucharest, Romania; annette.dancila@upb.ro (A.M.D.); simona.caprarescu@upb.ro (S.C.); constantin.bobirica@upb.ro (C.B.)

2 National Research and Development Institute for Chemistry and Petrochemistry-ICECHIM, Splaiul Independentei 202, 060021 Bucharest, Romania; violeta.purcar@icechim.ro

3 Faculty of Industrial Engineering and Robotics, Politehnica University of Bucharest, 060042 Bucharest, Romania; gabriel.garleanu@upb.ro (G.G.); claudia.borda@upb.ro (C.B.)

4 Institute of Research and Development "METAV" SA, C.A. Rosetti 31, 020011 Bucharest, Romania; eugeniu.vasile@upb.ro

5 Faculty of Engineering, Lucian Blaga University of Sibiu, 550024 Sibiu, Romania

* Correspondence: cristina.modrogan@upb.ro (C.M.); dan.dobrota@ulbsibiu.ro (D.D.); Tel.: +40-214-023-820 (C.M.); +40-0722-446-082 (D.D.)

Received: 7 April 2020; Accepted: 7 May 2020; Published: 10 May 2020

check for updates

\begin{abstract}
The realization of some composite materials that allow the best removal of $\mathrm{H}_{2} \mathrm{~S}$ from syngas was the main objective of this work. Thus, the optimization of the technological parameters for obtaining composites based on $\mathrm{Zn}$-Ti was achieved. The paper studies the influence of calcination temperature on the characteristics of the binary $\mathrm{ZnO}-\mathrm{TiO}_{2}$ system used to synthesize a composite material with suitable properties to be used subsequently for syngas treatment. The mineralogical and structural analyzes showed that starting with the calcination temperature of $700{ }^{\circ} \mathrm{C}$ the material synthetized is composed mainly of zinc orthotitanate which possess the corresponding characteristics to be finally used in the treatment of the syngas for its desulfurization. At this calcination temperature the material has a compact structure most likely due to sintering of the formed titanates. These composites have a texture that places them rather in the category of non-porous materials, the pore volume and their surface area obviously decreasing as the calcination temperature increases. A maximum sulfur removal degree of about $97 \%$ was obtained by using a composite synthetized at a temperature of $700{ }^{\circ} \mathrm{C}(\mathrm{ZT}-700)$.
\end{abstract}

Keywords: technological parameters; composites; optimization; syngas; hydrogen sulfide

\section{Introduction}

Gasification of renewable carbonaceous resources is currently one of the most important worldwide energy resources, mainly due to their availability, low cost, and environmental benefits $[1,2]$. Carbonaceous biomass such as sugar and starch crops (i.e., sugar beet, grains and tubers), oil crops (i.e., palm, rapeseed, sunflower), lignocellulosic plants (i.e., willow and eucalyptus), lignocellulosic biomass residue-derived agroforestry industries, and algae biomass, represents over $70 \%$ of all renewable energy production, and up to $10 \%$ of the worldwide total energy supply [3]. Steam gasification or supercritical water gasification in conjunction with wide range of catalysts such as alkaline earth metallic 
catalysts (i.e., $\mathrm{NaOH}, \mathrm{KOH}, \mathrm{Na}_{2} \mathrm{CO}_{3}, \mathrm{~K}_{2} \mathrm{CO}_{3}$ ), metal-based catalysts (i.e., $\mathrm{Ni}, \mathrm{Ce}, \mathrm{La}$ ), and mineral catalysts (i.e., dolomite and olivine), are the most currently used technologies to convert raw biomass materials into combustible gases generally called synthesis gases or syngas [4]. The resulting synthesis gas (syngas) can also be used to produce Fischer-Tropsch fuels, methanol, and oxo alcohols [5]. Syngas normally contains hydrogen $\left(\mathrm{H}_{2}\right)$ and carbon monoxide $(\mathrm{CO})$, but often it also contains carbon dioxide $\left(\mathrm{CO}_{2}\right)$, methane $\left(\mathrm{CH}_{4}\right)$, nitrogen $\left(\mathrm{N}_{2}\right)$ and, depending on the feedstock subjected to gasification, a higher or lesser amount of hydrogen sulfide $\left(\mathrm{H}_{2} \mathrm{~S}\right)$, as well as small amounts of other compounds and particles. For example, the percentage of sulfur in the refuse from gardens (green wastes) is $0.18 \%$, in the pine sawdust is $0.57 \%$, in the wood chips is $0.02 \%$, in the wood residue is $0.2 \%$, and in the coffee bean husks is $0.07 \%$ [6]. Therefore, the gas resulting from the gasification of these materials will contain different amounts of $\mathrm{H}_{2} \mathrm{~S}$. In order to be used in power producing equipment such as gas engines, micro gas turbines, or fuel cells, the syngas must be conditioned in order to meet the required operation conditions [7]. The main syngas contaminants with detrimental effects for such equipment are solid particles, tar, $\mathrm{H}_{2} \mathrm{~S}, \mathrm{HCl}$, and alkali compounds such as $\mathrm{NaOH}$ and $\mathrm{KOH}$ [8].

$\mathrm{H}_{2} \mathrm{~S}$ is known as a toxic odorous gas that causes many technical and environmental problems such as corrosion of equipment, poisoning of catalysts, and formation of acid rain, and therefore its removal from syngas is a priority within gasification plants [9]. In this regard, based on the numerous studies carried out in this field, a wide range of methods for removing $\mathrm{H}_{2} \mathrm{~S}$ from syngas or other residual gas streams have been identified, tested and applied. Except for the direct conversion of $\mathrm{H}_{2} \mathrm{~S}$ to sulfur through the Claus process, these methods are conventionally divided into two categories, namely cold gas cleanup (wet and dry) and hot gas cleanup methods. Compared to the first one, the second category has received more attention in recent years due to the advantages it offers, such as avoiding the costs related to cooling the syngas that led to increasing the efficiency of the $\mathrm{H}_{2} \mathrm{~S}$ removing process, as well as avoiding the generation of waste effluents that require new treatment stages [10]. Therefore, a large assortment of sorbents and catalysis were prepared and tested in different conditions in order to identify the optimum conditions that will ensure the removal of $\mathrm{H}_{2} \mathrm{~S}$ with the highest efficiency [11-14]. Of these, sorbents based on $\mathrm{Zn}$-Ti were intensively studied due to their proven efficacy for removing $\mathrm{H}_{2} \mathrm{~S}$ in high temperature operating conditions (i.e., $\mathrm{H}_{2} \mathrm{~S}$ conversion at $750{ }^{\circ} \mathrm{C}$ is close to $100 \%$ ) [15].

Zinc titanates have been synthesized in different ways (i.e., solid state reaction, polymeric precursor method, hydrothermal method, molten salt method, precipitation method, etc.) and heat treated (calcination) at different temperatures in order to obtain a composite with high physico-chemical stability and adequate reactive and regenerative capacity [16-19]. Generally, the $\mathrm{ZnO}-\mathrm{TiO}_{2}$ binary system may consist of five types of zinc titanates, including $\mathrm{ZnTiO}_{3}\left(\mathrm{ZnO}-\mathrm{TiO}_{2}\right), \mathrm{Zn}_{2} \mathrm{TiO}_{4}\left(2 \mathrm{ZnO}-\mathrm{TiO}_{2}\right)$, and $\mathrm{Zn}_{2} \mathrm{Ti}_{3} \mathrm{O}_{8}\left(2 \mathrm{ZnO}-3 \mathrm{TiO}_{2}\right)$, but for high temperature desulfurization of syngas only $\mathrm{Zn}_{2} \mathrm{TiO}_{4}$ is the most important [20]. However, the end product composition is strongly dependent on the synthesis method and the heat treatment applied [21].

Therefore, the objective of this paper is to investigate through mineralogical, morphological, structural and textural analyzes the influence of calcination temperature on the characteristics of $\mathrm{ZnO}-\mathrm{TiO}_{2}$ composites synthesized through the precipitation method based on microsized $\mathrm{ZnO}$ and $\mathrm{TiO}_{2}$ powder mix and ammonium bicarbonate $\left(\mathrm{NH}_{4} \mathrm{HCO}_{3}\right)$ solution. The $\mathrm{ZnO}-\mathrm{TiO}_{2}$ composite that exhibited the best characteristics was tested for sulfur removal from a simulated gas stream.

\section{Materials and Methods}

\subsection{Materials}

Zinc oxide ( $\mathrm{ZnO}$, würtzit form), titanium dioxide $\left(\mathrm{TiO}_{2}\right.$, anatase form), and ammonium bicarbonate $\left(\mathrm{NH}_{4} \mathrm{HCO}_{3}\right)$ were purchased from Sigma-Aldrich (St. Louis, MO, USA). Ammonium bicarbonate solution of $12.5 \%$ (wt.) was freshly prepared by adding a suitable amount of deionized water. Deionized water was used throughout all experiments. 


\subsection{Composites Synthesis}

The $\mathrm{ZnO}-\mathrm{TiO}_{2}$ composites were synthetized through a simple precipitation method which is described in the following. In this respect, $\mathrm{ZnO}$ and $\mathrm{TiO}_{2}$ powders were initially dry mixed at a $\mathrm{ZnO}: \mathrm{TiO}_{2}$ molar ratio of 2:1 for $30 \mathrm{~min}$, after which a solution of ammonium bicarbonate $(12.5 \%$ $\mathrm{NH}_{4} \mathrm{HCO}_{3}$ ) was gradually added for 60 min until a consistent paste was obtained. Next, the paste obtained was vacuum oven dried at $105^{\circ} \mathrm{C}$ until a constant mass was reached. The dried paste was pre-calcined at $300{ }^{\circ} \mathrm{C}$ for four hours. The obtained product was divided into five samples that were subjected to calcination for four hours at different temperatures. The synthesis conditions are presented in Table 1.

Table 1. Composites synthesis conditions.

\begin{tabular}{|c|c|c|c|}
\hline Sample Code & ZnO:TiO 2 Molar Ratio & Preparation Conditions & $\begin{array}{c}\text { Calcination } \\
\text { Temperature, }{ }^{\circ} \mathrm{C}\end{array}$ \\
\hline ZT-300 & & Dry mixing of $\mathrm{ZnO}$ and $\mathrm{TiO}_{2}$ for $30 \mathrm{~min}$ & - \\
\hline ZT-500 & $2: 1$ & $\begin{array}{l}\text { Semi-wet mixing of the } \mathrm{ZnO} \text { and } \mathrm{TiO}_{2} \\
\text { mixture with ammonium bicarbonate } \\
\left(\mathrm{NH}_{4} \mathrm{HCO}_{3}\right) \text { solution }(12.5 \% \text { wt.) for } 60 \mathrm{~min}\end{array}$ & 500 \\
\hline ZT-600 & & Drying at $105^{\circ} \mathrm{C}$ to the constant mass & 600 \\
\hline ZT-700 & & Pre-calcination at $300^{\circ} \mathrm{C}$ for $4 \mathrm{~h}$ & 700 \\
\hline ZT-800 & & Calcination at different temperatures for $4 \mathrm{~h}$ & 800 \\
\hline
\end{tabular}

\subsection{Composites Characterization}

The phase composition analysis of the composites was performed by X-ray diffractometry (XRD) using a model 6000 diffractometer (Shimadzu, Duisburg, Germany; -20 Bragg-Brentano geometry, using the $\mathrm{CuK} \alpha$ characteristic radiations). The elimination of the $\mathrm{CuK} \beta$ component was achieved by a Ni filter. The experimental data were digitally collected through "step by step" scanning method in the $2 \theta$ angle interval of 10-90 degrees. Scanning Electron Microscopy (SEM) was performed by using a S2600N scanning electron microscope (Hitachi, Berkshire, United Kingdom). The X-ray qualitative and quantitative microanalyses were performed with an X-ray spectra energy dispersion of Röntec type Brunauer-Emmett-Teller (BET) type. The textural analysis was performed by using an ASAP 2020 physisorption analyzer (Micromeritics „, Unterschleissheim, Germany). The samples were first degassed for $2 \mathrm{~h}$ at a temperature of $150{ }^{\circ} \mathrm{C}$ and pressure of $0.1 \mathrm{~Pa}$ and then subjected to analysis. The $\mathrm{N}_{2}$ adsorption-desorption isotherms of composites were determined at $\mathrm{N}_{2}$ liquefaction temperature $(77.35 \mathrm{~K})$. The surface area was determined from the isotherms data by using Brunauer-Emmett-Teller (BET) method, while the pore size distribution and the pore volume were calculated by using Barrett-Joyner-Halenda (BJH) method. FTIR spectra of composites were recorded with a Tensor 37 instrument (Bruker, Durham, United Kingdom), in attenuated total reflectance mode (ATR, Golden Gate diamond unit). The wavelength range was from 4000 to $400 \mathrm{~cm}^{-1}$ at 64 scans per spectrum, with a resolution of $4 \mathrm{~cm}^{-1}$.

\section{4. $\mathrm{ZnO}-\mathrm{TiO}_{2}$ Composite Testing}

\subsection{1. ${\mathrm{ZnO}-\mathrm{TiO}_{2}}_{2}$ Composite Sulfurization}

Two grams of $\mathrm{ZnO}-\mathrm{TiO}_{2}$ composite with a particle size less than $1 \mathrm{~mm}$ were sulfurized for five hours by passing a $\mathrm{H}_{2} \mathrm{~S}$ gas stream through a tubular reactor heated at a temperature of $500 \pm 2{ }^{\circ} \mathrm{C}$ with a flow rate of $50 \mathrm{~mL} / \mathrm{min} . \mathrm{H}_{2} \mathrm{~S}$ was generated by the acid attack ( $300 \mathrm{~mL}$ hydrochloric acid- $\mathrm{HCl}$, $30-35 \%$ by mass) of $50 \mathrm{~g}$ of iron sulfide (FeS). Prior to sulfurization, the ${\mathrm{ZnO}-\mathrm{TiO}_{2}}_{2}$ composite was activated by passing an argon stream through the tubular reactor heated to $300^{\circ} \mathrm{C}$ for $20 \mathrm{~min}$. A sketch of the sulfurization laboratory plant is shown in Figure 1. The installation used for sulfurization is not a standard one. It was developed in-house by the authors. 


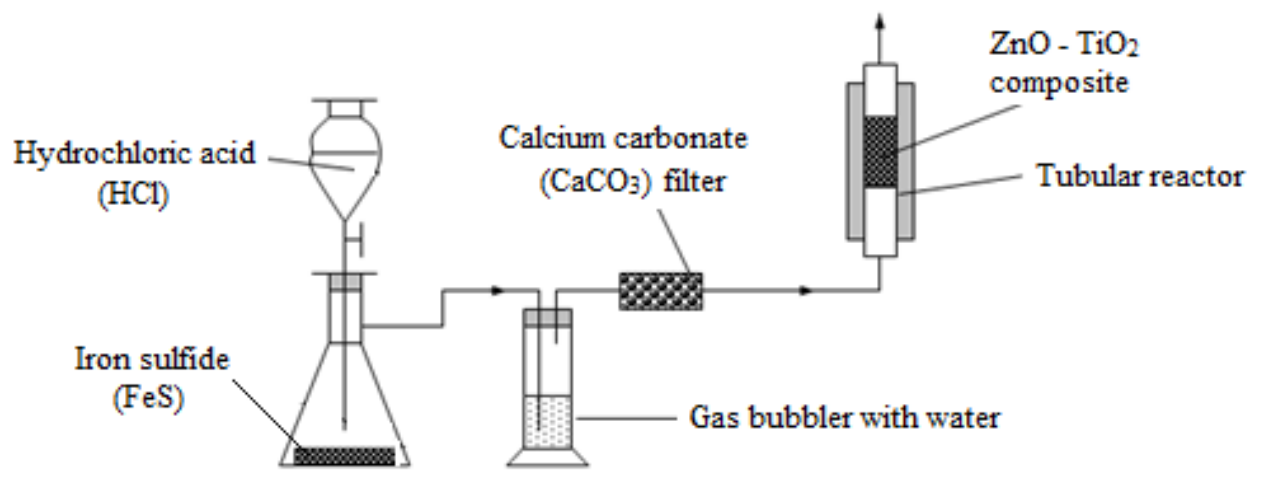

Figure 1. The sketch of the laboratory sulfurization plant.

\subsection{2. $\mathrm{ZnO}-\mathrm{TiO}_{2}$ Composite Regeneration}

The regeneration of the sulfurized $\mathrm{ZnO}-\mathrm{TiO}_{2}$ composite was carried out by combustion the samples into an oxygen-excess atmosphere. In this respect, $0.2 \mathrm{~g}$ of sulfurized $\mathrm{ZnO}-\mathrm{TiO}_{2}$ composite with a particle size less than $1 \mathrm{~mm}$ were introduced into an electrically heated oven, preheated at a temperature of $400{ }^{\circ} \mathrm{C}$, which is connected to the gas capture and analysis facility of the formed sulfur dioxide $\left(\mathrm{SO}_{2}\right)$. The heating of the oven continues up to a temperature of $950{ }^{\circ} \mathrm{C}$ with a rate of $10^{\circ} \mathrm{C} / \mathrm{min}$. The sulfur dioxide formed is trapped in an iodine solution $\left(\mathrm{I}_{2}, 0.1 \mathrm{~N}\right)$ added progressively to the bubbling vessel until it has not decolorized anymore. The excess iodine is subsequently titrated with sodium thiosulfate solution $\left(\mathrm{Na}_{2} \mathrm{~S}_{2} \mathrm{O}_{3}, 0.1 \mathrm{~N}\right)$ in the presence of starch solution. A sketch of the laboratory plant is shown in Figure 2. The method and the installation used for composite regeneration are not standard. Both of them were developed by us.

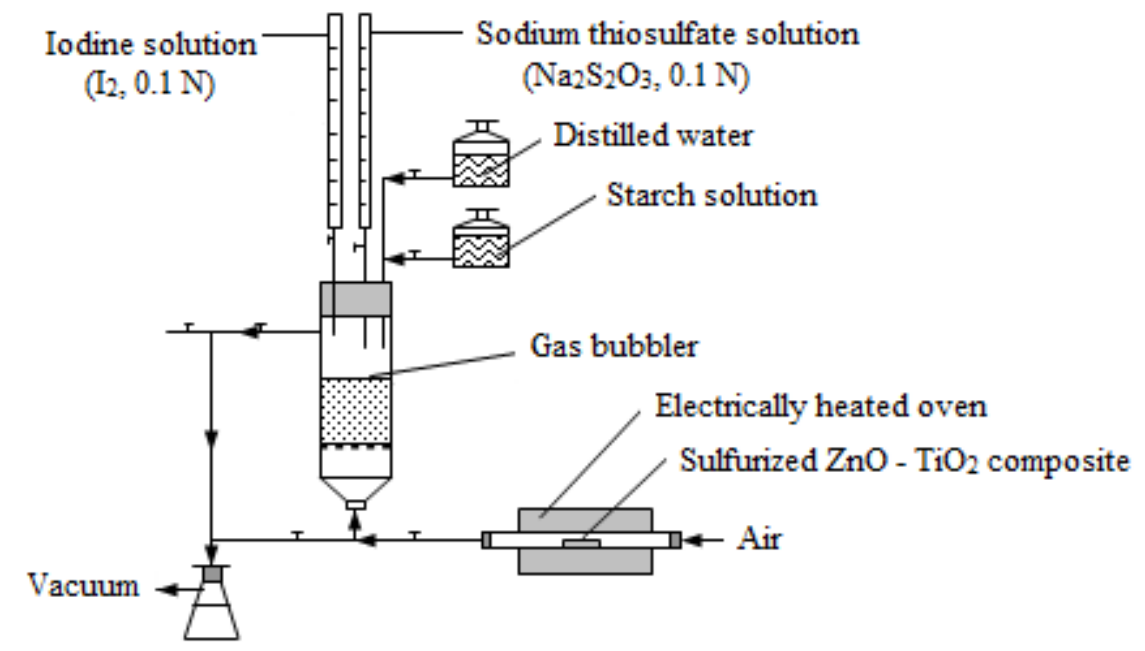

Figure 2. The sketch of the laboratory plant for sulfurized $\mathrm{ZnO}-\mathrm{TiO}_{2}$ composite regeneration.

\section{Results and Discussion}

\subsection{X-Ray Diffractometry}

The XRD spectra of the synthesized composites (Figure 3) indicate the significant influence of the temperature at which the heat treatment is carried out. As can be seen, in the low temperature range $\left(300{ }^{\circ} \mathrm{C}\right.$ and $500{ }^{\circ} \mathrm{C}$ ) only $\mathrm{ZnO}$ in the wurtzite form (peaks located at $2 \theta=31.82^{\circ}, 34.471^{\circ}, 36.309^{\circ}$, $47.592^{\circ}, 56.647^{\circ}, 67.996^{\circ}$, and $69.167^{\circ}-\mathrm{JCPDS}$ card reference code 01-070-8072) and $\mathrm{TiO}_{2}$ in the anatase form (peaks located at $2 \theta=25.346^{\circ}, 37.846^{\circ}, 48.084^{\circ}, 53.947^{\circ}, 55.112^{\circ}$, and $70.336^{\circ}$-JCPDS card reference code 01-084-1286) as well as in the rutile form (peaks located at $2 \theta=36.302^{\circ}, 56.647^{\circ}$, and $62.890^{\circ}$-JCPDS card reference code 01-073-1765) appear in the ZT-300 and ZT-500 composites XRD spectra (Figure 3a,b). 
As the temperature rises $\left(600{ }^{\circ} \mathrm{C}\right)$, zinc titanates such as $\mathrm{ZnTiO}_{3}$ and $\mathrm{Zn}_{2} \mathrm{TiO}_{4}$ begin to appear in the ZT-600 composite XRD spectrum (Figure 3c). The peaks were attributed to cubic crystallization system of $\mathrm{Zn}_{2} \mathrm{TiO}_{4}$ located at $2 \theta=29.939^{\circ}, 35.217^{\circ}, 53.0531^{\circ}$, and $56.711^{\circ}$ (JCPDS card reference code 01-073-0578), and to rhomboidal crystallization system of $\mathrm{ZnTiO}_{3}$ located at $2 \theta=32.825^{\circ}, 38.771^{\circ}$, $53.015^{\circ}, 56.844^{\circ}, 62.907^{\circ}$, and $77.956^{\circ}$ (JCPDS card reference code 01-073-0547). At this temperature the unreacted weight percent of $\mathrm{ZnO}$ is $53.5 \%$ and unreacted weight percent of $\mathrm{TiO}_{2}$ is $22.2 \%$ in anatase form and $10.1 \%$ in rutile form. The weight percent of $\mathrm{Zn}_{2} \mathrm{TiO}_{4}$ formed is $8.1 \%$ and the weight percent of $\mathrm{ZnTiO}_{3}$ formed is $6.1 \%$.
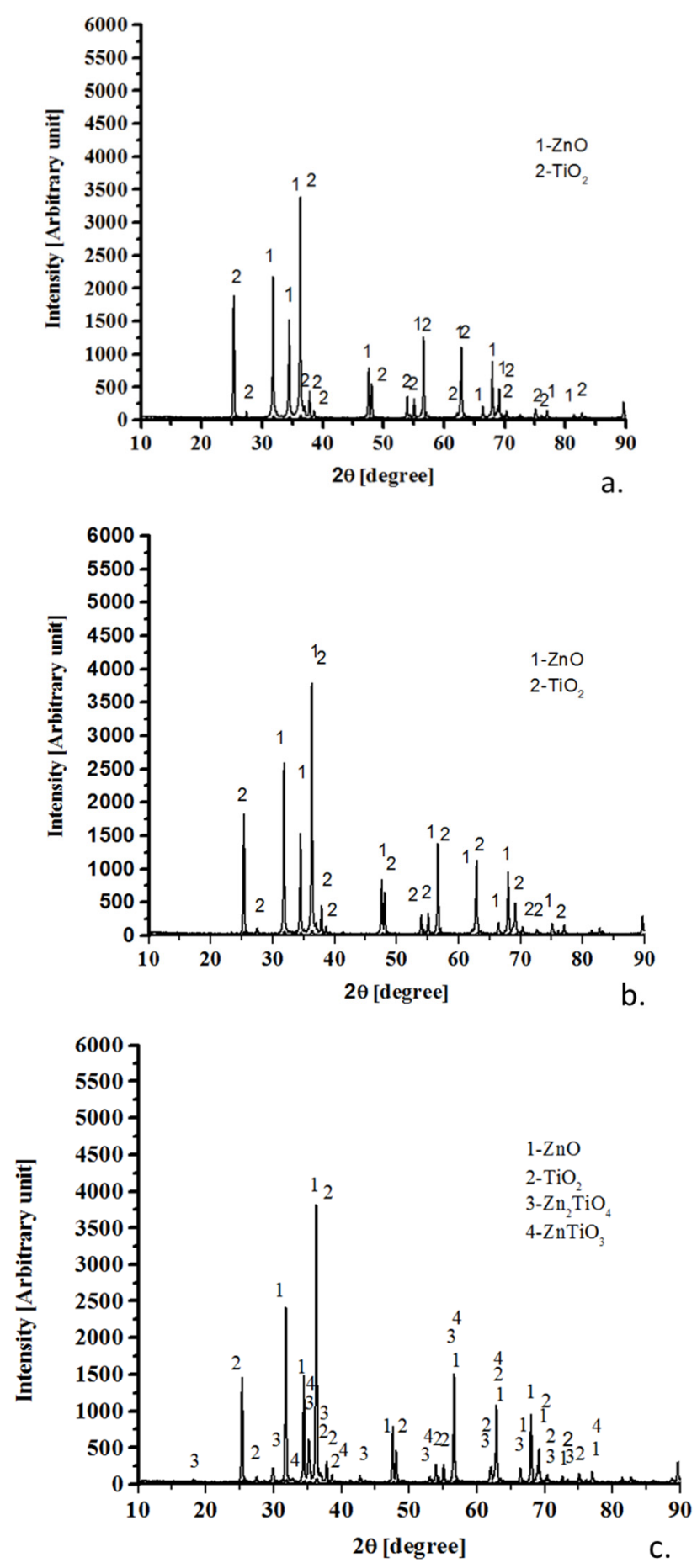

Figure 3. Cont. 

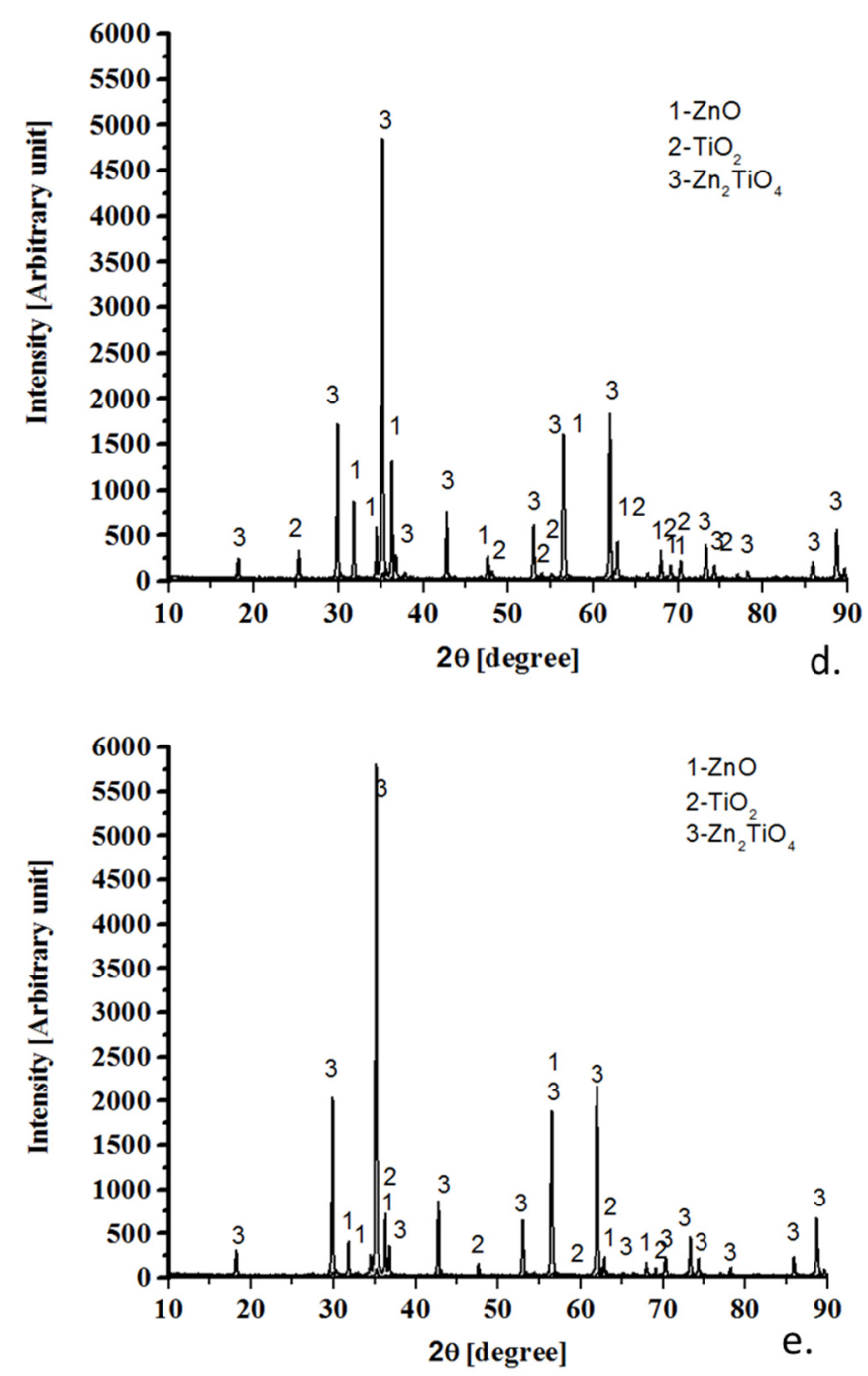

Figure 3. X-ray diffraction (XRD) patterns of synthetized composites: (a) ZT-300, (b) ZT-500, (c) ZT-600, (d) ZT-700, (e) ZT-800.

The spectra of ZT-700 and ZT-800 (Figure 3d,e) show that $\mathrm{Zn}_{2} \mathrm{TiO}_{4}$ represents the major phase of these synthetized composites (peaks located at $2 \theta=18.161^{\circ}, 29.939^{\circ}, 35.217^{\circ}, 36.387^{\circ}, 42.627^{\circ}, 53.053^{\circ}$, $56.641^{\circ}, 62.933^{\circ}$, and $73.411^{\circ}$-JCPDS card reference code 01-073-0578). Thus, in the case of ZT-700, the weight percent of $\mathrm{Zn}_{2} \mathrm{TiO}_{4}$ is $72.7 \%$, and $6.1 \% \mathrm{TiO}_{2}$ (rutile form) and $21.1 \% \mathrm{ZnO}$ remains unreacted. Regarding ZT-800, the weight percent of $\mathrm{Zn}_{2} \mathrm{TiO}_{4}$ is $88 \%$, and only $1.8 \% \mathrm{TiO}_{2}$ (rutile form) and $9.8 \%$ $\mathrm{ZnO}$ remains unreacted. The difference regarding the participation in the reaction of the two oxides components of the $\mathrm{ZnO}-\mathrm{TiO}_{2}$ binary system is that at high calcination temperatures titanium ions $\left(\mathrm{Ti}^{4+}\right)$ and zinc ions $\left(\mathrm{Zn}^{2+}\right)$ diffuse at different rates through the zinc oxide layer, the rate of diffusion of titanium ions being greater than that of zinc ions [22,23].

\subsection{Infrared Spectroscopy}

The FTIR spectra of the synthetized composites are presented in Figure 4. As can be seen, the spectra corresponding to the composites ZT-300, ZT-500, and ZT-600 show a broad absorption band in the range of 3371 to $3381 \mathrm{~cm}^{-1}$, which was attributed to the $\mathrm{O}-\mathrm{H}$ stretching vibration of the water molecules. This absorption band disappears in the spectra of the composites heat-treated at high temperatures, namely ZT-700 and ZT-800, which is an indicator for the complete dehydration of the $\mathrm{ZnO}-\mathrm{TiO}_{2}$ binary 
system. The absorption bands in the frequency intervals of 2318 to $2353 \mathrm{~cm}^{-1}$ was associated with the free $\mathrm{CO}_{2}$ molecule existing in the atmospheric air [20].

Also, the absorption bands (spectra of ZT-300, ZT-500, and ZT-600) in the range of 1409-1411 $\mathrm{cm}^{-1}$ and those in the range of $1501-1504 \mathrm{~cm}^{-1}$ have been associated with carbonate species which could be derived from the zinc titanate precursors. The peaks located in the range of $722-797 \mathrm{~cm}^{-1}$ in the spectra of ZT-300, ZT-500, ZT-600, and ZT-700 are assigned to Ti-O stretching vibration in the octahedral $\mathrm{TiO}_{6}$ group which is present in $\mathrm{TiO}_{2}, \mathrm{ZnTiO}_{3}$ and $\mathrm{Zn}_{2} \mathrm{TiO}_{4}[16,17,24]$. It should be noted that, of all these spectra, the one corresponding to the ZT-700 has an adsorption band in this frequency interval with the lowest intensity. However, unlike the others, it presents a new absorption band located at $549 \mathrm{~cm}^{-1}$ which was assigned to the same Ti-O stretching vibration which is this time associated with the octahedral $\mathrm{TiO}_{6}$ group in the $\mathrm{Zn}_{2} \mathrm{TiO}_{4}$. The spectrum of $\mathrm{ZT}-800$ has a single absorption band located at approximately the same frequency as in the case of ZT-700 $\left(548 \mathrm{~cm}^{-1}\right)$ spectrum, which is also associated with $\mathrm{TiO}_{6}$ group in the $\mathrm{Zn}_{2} \mathrm{TiO}_{4}$. The peak that appears at $485 \mathrm{~cm}^{-1}$ in the spectra of ZT-300, ZT-500, and ZT-600 was assigned to the stretching vibrations of Zn-O bond in ZnO. All these results indicate a progressive transformation of the $\mathrm{ZnO}-\mathrm{TiO}_{2}$ binary system with the increase of the calcination temperature, which becomes predominantly mono-component (i.e., $\mathrm{Zn}_{2} \mathrm{TiO}_{4}$ ) at calcination temperatures above $700{ }^{\circ} \mathrm{C}$. These results are consistent with those obtained by XRD analysis.

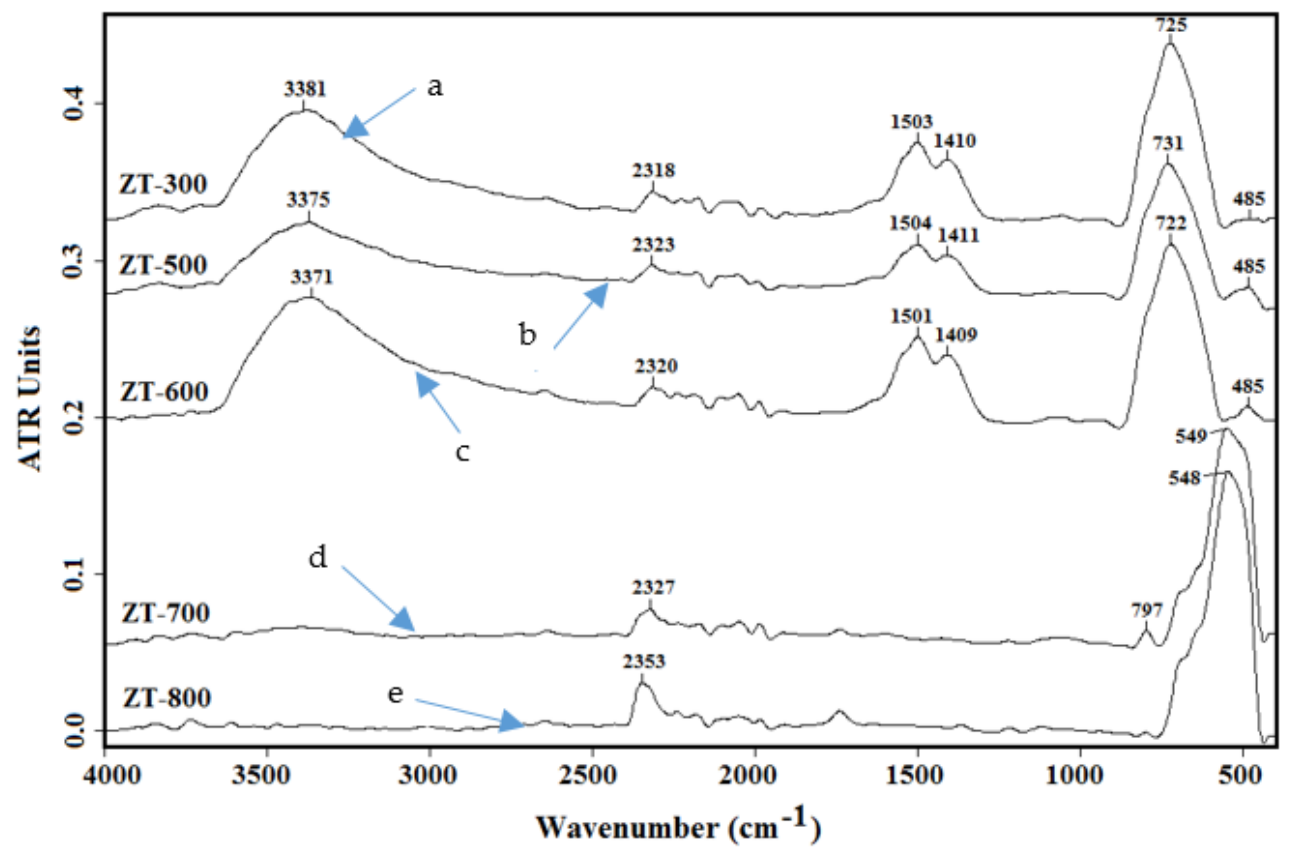

Figure 4. Fourier transform infrared (FT-IR) spectra of synthetized composites: (a) ZT-300, (b) ZT-500, (c) ZT-600, (d) ZT-700, (e) ZT-800.

\subsection{Scanning Electron Microscopy}

Figure 5 shows the electron micrographs of the synthetized composites. In this respect, the electron micrograph for the sample ZT-300 shows the presence of three types of particles of different sizes. The largest ones, having dimensions ranged between 150-320 nm, were attributed to the $\mathrm{ZnO}$ (würtzit form). Smaller particles deposits with the dimensions ranged between 13.4-16.4 nm, which are attributed to the $\mathrm{TiO}_{2}$ in the anatase form, are grouped on their surface. Small amounts of intermediate-size particles were attributed to the $\mathrm{TiO}_{2}$ in the rutile form, the dimensions of which vary between $50-75 \mathrm{~nm}$. 

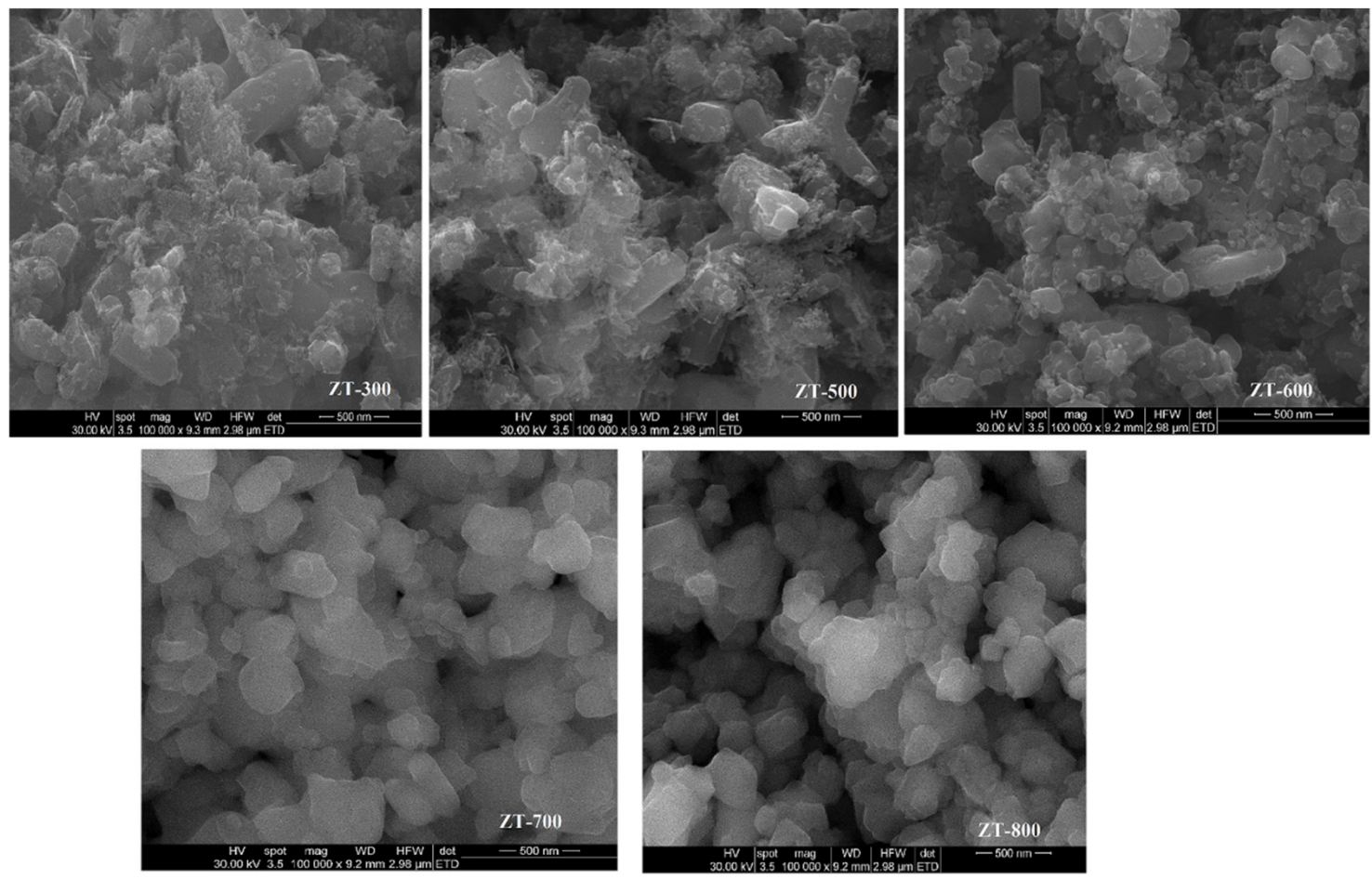

Figure 5. Scanning electron microscope (SEM) images of synthetized composites $(100,000 \times$ magnification; horizontal field of width $\mathrm{HFW}=2.98 \mu \mathrm{m}$ ).

It is also noted that some particles have brighter edges, which suggests their orientation at different heights. The electron micrograph corresponding to the ZT-500 is similar to that of ZT-300 showing large $\mathrm{ZnO}$ particles with dimensions ranging between $119-200 \mathrm{~nm}, \mathrm{TiO}_{2}$ particles in anatase form, whose dimensions are small, ranging between $15-22 \mathrm{~nm}$, as well as intermediate-size particles of $\mathrm{TiO}_{2}$ in the rutile form with dimensions ranged between $80-100 \mathrm{~nm}$. The morphology of ZT-600 begins to look uniform with the dimensions of particles ranging between 18-105 nm. At this calcination temperature, $\mathrm{TiO}_{2}$ particles in the anatase form get polygonal shapes in comparison with ZT-500 in which the $\mathrm{TiO}_{2}$ particles do not have a defined form. ZT-700 has a uniform morphology with particles having similar dimensions and regular forms. This morphology suggests the conversion of a large part of $\mathrm{TiO}_{2}$ and $\mathrm{ZnO}$ to zinc titanates, as was also confirmed by XRD results. The particles have a clear outline being in the form of plates stacked one above another with the dimensions ranging between $100-350 \mathrm{~nm}$. Over the calcination temperature of $700^{\circ} \mathrm{C}$ zinc titanates particles get sintered and the contours of the particles begin to disappear (electron micrograph of ZT-800). The dimension of particles varies between $110-177 \mathrm{~nm}$.

\subsection{Textural Characterization of Synthetized Composites}

To characterize the synthesized composites from a textural point of view, a BET analysis of their surfaces was carried out. The adsorption-desorption isotherms as well as the particle size distribution of the synthetized composites are presented in Figure 6.

According to the IUPAC classification [25], the measured adsorption-desorption isotherms of ZT-500 and ZT- 600 are of type II (the relative pressure-p/ $\mathrm{p}_{0}$ at which the multilayer adsorption begins is approximately 0.2 for ZT-500 and 0.1 for ZT-600) which indicates that these composites have developed a predominantly non-porous structure with only a limited number of micropores and mesopores.

However, the small type $\mathrm{H} 3$ hysteresis that appears on these isotherms indicates some plate-like particles with irregular and slit-shaped pores. The measured adsorption-desorption isotherms of ZT-700 looks rather to be of type III which is also associated with a non-porous material. However, the open hysteresis that appears on the isotherm suggests a small micropore volume developed in this type of 
composite with the presence of some very narrow slit pores or bottle shaped pores. A non-homogenous pore size distribution was recorded for all synthetized composites.
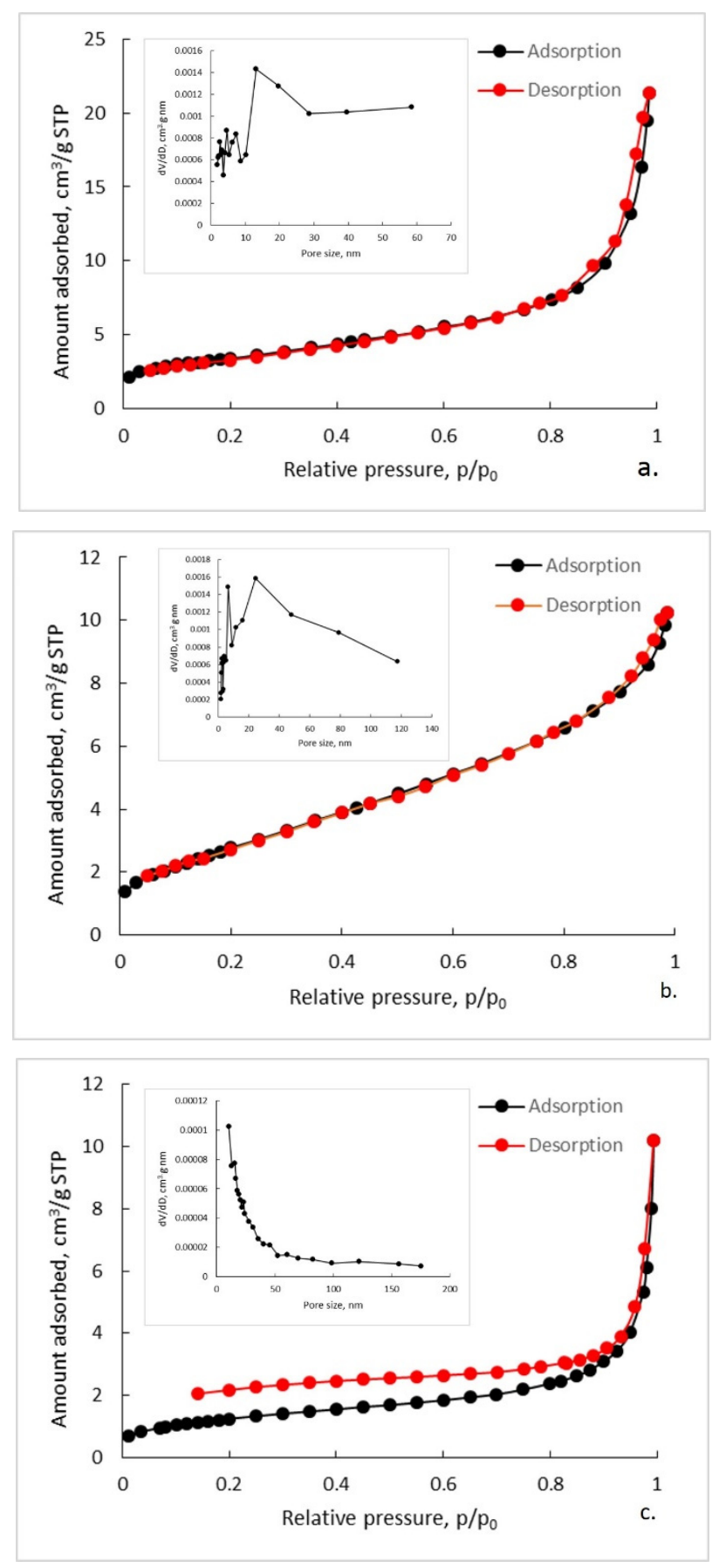

Figure 6. Nitrogen adsorption-desorption isotherms of of synthetized composites: (a) ZT-500, (b) ZT-600, (c) ZT-700. Particle size distribution as inset graphs.

Figure 7 shows the variation of BET surface area and pore volume of the synthesized composites according to the calcination temperature. As can be seen, both BET surface area and pore volume decrease with the increasing of calcination temperature. This is most probably due to the increasingly pronounced sintering of the formed zinc titanates, which leads to the closure of the pores [26]. According to the results obtained from the BET analysis, the largest surface area was registered for ZT-500, this being $11.97 \mathrm{~m}^{2} / \mathrm{g}$, but as the XRD results have shown, at this calcination temperature the material consists only of $\mathrm{Ti}$ and $\mathrm{Zn}$ 
oxides. With the occurrence of zinc titanates in the system starting with the calcination temperature of $600{ }^{\circ} \mathrm{C}$, the specific surface begins to decrease, so that for ZT- 600 this is $10.35 \mathrm{~m}^{2} / \mathrm{g}$ and for ZT-700 it is only $4.58 \mathrm{~m}^{2} / \mathrm{g}$. Similar trend was recorded for pore volume of synthetized composites namely, $0.031 \mathrm{~cm}^{3} / \mathrm{g}$ for ZT-500, $0.015 \mathrm{~cm}^{3} / \mathrm{g}$ for ZT-600, and $0.014 \mathrm{~cm}^{3} / \mathrm{g}$ for ZT-700. This very small pore volume suggests a non-porous-like structure of the synthetized composites [27,28].

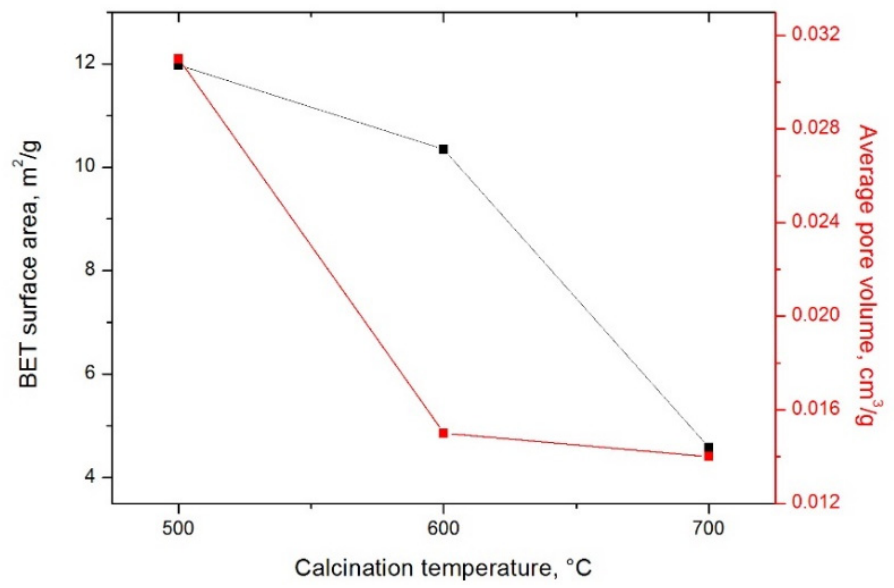

Figure 7. Influence of calcination temperature on the BET surface area and pore volume of the synthetized composites.

\section{5. $\mathrm{ZnO}-\mathrm{TiO}_{2}$ Composite Testing}

From the mineralogical, morphological, structural and textural analyzes it can be concluded that $\mathrm{ZnO}-\mathrm{TiO}_{2}$ composite obtained by calcination at $700{ }^{\circ} \mathrm{C}$ (ZT-700) exhibits the best physicochemical characteristics and, therefore has been tested in respect with its capacity to remove $\mathrm{H}_{2} \mathrm{~S}$ from a simulated gas stream. The removal degree of sulfur from simulated gas stream obtained with ZT-700 was established from the tests results. The obtained results are presented in Table 2 and Figure 8.

Table 2. Sulfur content and the degree of $\mathrm{ZnO}$ consumption in the sample.

\begin{tabular}{|c|c|c|c|c|}
\hline Sample Code & $\begin{array}{c}\mathrm{ZnO}: \mathrm{TiO}_{2} \\
\text { Molar Ratio }\end{array}$ & $\begin{array}{c}\text { Theoretical Sulfur } \\
\text { Content }{ }^{*}\left(S_{t}\right), \%(w t .)\end{array}$ & $\begin{array}{l}\text { Experimental Sulfur } \\
\text { Content }\left(S_{e}\right), \% \text { (wt.) }\end{array}$ & $\begin{array}{c}\text { Sulfur Removal } \\
\text { Degree, } \%\end{array}$ \\
\hline ZT 700 & $2: 1$ & 23.32 & 22.63 & 97.04 \\
\hline
\end{tabular}

* The theoretical amount of sulfur is determined by the molar ratio of oxides $\left(\mathrm{ZnO}: \mathrm{TiO}_{2}=2: 1\right)$ relative to $100 \mathrm{~g}$ of sulfur-saturated mass of sample.

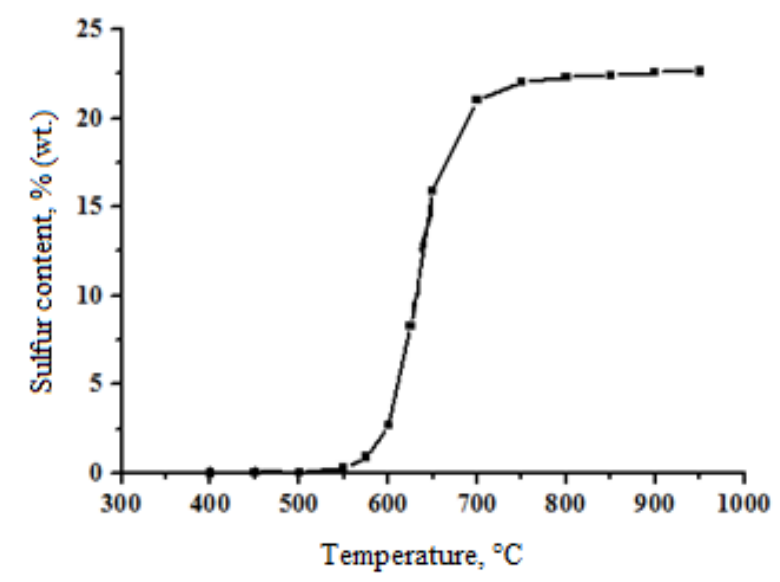

Figure 8. The amount of sulfur removed from the ZT-700 as a function of the calcination temperature. 
The equations of the chemical reactions as well as the calculations underlying the experimental determination of the experimental sulfur content in the sample are presented in Equations (1)-(6):

$$
\begin{gathered}
\mathrm{FeS}+2 \mathrm{HCl} \rightarrow \mathrm{FeCl}_{2}+\mathrm{H}_{2} \mathrm{~S} \uparrow \\
\mathrm{H}_{2} \mathrm{~S}+\mathrm{ZnO} \rightarrow \mathrm{ZnS}+\mathrm{H}_{2} \mathrm{O} \\
\mathrm{ZnS}+\frac{3}{2} \mathrm{O}_{2} \rightarrow \mathrm{ZnO}+\mathrm{SO}_{2} \\
\mathrm{SO}_{2}+\mathrm{I}_{2}+2 \mathrm{H}_{2} \mathrm{O} \rightarrow \mathrm{H}_{2} \mathrm{SO}_{4}+2 \mathrm{HI} \\
\mathrm{I}_{2}+2 \mathrm{Na}_{2} \mathrm{~S}_{2} \mathrm{O}_{3} \rightarrow 2 \mathrm{NaI}+\mathrm{Na}_{2} \mathrm{~S}_{4} \mathrm{O}_{6} \\
\mathrm{~S}_{e}=\frac{0.0016 \times\left(V_{1} \times f_{1}-V_{2} \times f_{2}\right)}{m} \times 100
\end{gathered}
$$

The degree of sulfur removal obtained with ZT-700 was determined with Equation (7):

$$
\eta=\frac{S_{e}}{S_{t}} \times 100
$$

where $S_{e}$ is the experimental sulfur content, $\%$ (wt.); $S_{t}$ is the theoretical sulfur content, $\%$ (wt.), $\eta$ is the sulfur removal degree, $\% ; V_{1}$ is the volume of iodine consumed up to the total regeneration of the sulfurized ZT-700, $\mathrm{mL} ; \mathrm{V}_{2}$ is the volume of $0.1 \mathrm{~N}$ sodium thiosulfate solution used for titration, $\mathrm{mL} ; \mathrm{f}_{1}$ is the correction factor of the $0.1 \mathrm{~N}$ iodine solution; $\mathrm{f}_{2}$ is the correction factor of the $0.1 \mathrm{~N}$ iodine solution sodium thiosulfate solution; $\mathrm{m}$ is the mass of the sulfurized ZT-700 sample, g; 0.0016 is the amount of sulfur (g) corresponding to $1 \mathrm{~cm}^{3}$ of $0.1 \mathrm{~N}$ iodine solution.

As it shown in Figure 8, the oxidation of zinc sulfide $(\mathrm{ZnS})$ begins at low temperature values $\left(400-500{ }^{\circ} \mathrm{C}\right.$ ), and the maximum oxidation rate is reached in the temperature range of $600-700{ }^{\circ} \mathrm{C}$.

\begin{tabular}{|c|c|c|c|}
\hline Sorbent/Catalyst & Operational Conditions & Removal Efficiency, \% & Reference \\
\hline $\begin{array}{l}\text { Dolomite and Ni-based catalyst } \\
\left(\mathrm{Ni} 11 \%, \mathrm{CaO} 6-9 \%, \mathrm{Al}_{2} \mathrm{O}_{3}\right. \\
76-82 \%)\end{array}$ & $\begin{array}{l}\text { Temperature: } 850{ }^{\circ} \mathrm{C}, \\
\text { atmospheric pressure, } \\
\text { saturated conditions }\end{array}$ & over 97 & [29] \\
\hline $\begin{array}{l}\text { G-201 and G-202 sorbents }(\mathrm{Zn} / \mathrm{Ti} \\
\text { molar ratio of } 1.5 \text { and } 1.0 \\
\text { respectively) }\end{array}$ & $\begin{array}{c}\text { Temperature: } 550-650{ }^{\circ} \mathrm{C} \\
\text { Pressure: } 0.8 \mathrm{mpa}\end{array}$ & over 99 & {$[30]$} \\
\hline $\begin{array}{l}\text { Non-thermal plasma combined } \\
\text { with } 5 \% \mathrm{MoS}_{2} / \mathrm{Al}_{2} \mathrm{O}_{3}\end{array}$ & $\begin{array}{l}\text { Low temperature }(120 \\
\left.{ }^{\circ} \mathrm{C}\right) \text { and atmospheric } \\
\text { pressure }\end{array}$ & 98-100 & [31] \\
\hline Zinc oxide & $\begin{array}{l}\text { Around } 2 \% \text { humidity } \\
\text { and temperature } 460{ }^{\circ} \mathrm{C}\end{array}$ & near the 100 & [13] \\
\hline $\begin{array}{l}\text { Monolithic sorbent ZTC (Zn:Ti:Co } \\
=1: 1: 0.25) 60 \% \text {, natural clay } 27 \% \text {, } \\
\text { silica gel } 3 \% \text {, colloidal dispersion } \\
\text { of graphite } 10 \%\end{array}$ & Temperature: $540^{\circ} \mathrm{C}$ & $99.6-99.9$ & [32] \\
\hline $\begin{array}{l}\mathrm{ZT}-700\left(\mathrm{ZnO}: \mathrm{TiO}_{2} \text { molar ratio of }\right. \\
\left.2: 1 ; \text { calcinated at } 700{ }^{\circ} \mathrm{C}\right)\end{array}$ & Temperature: $600-700^{\circ} \mathrm{C}$ & 97 & This work \\
\hline
\end{tabular}
At these temperatures a content of sulfur of approximate $23 \% \mathrm{wt}$. is reached, which corresponds to a maximum sulfur removal degree of approximate $97 \%$. Table 3 presents a comparative study on the efficiency of $\mathrm{H}_{2} \mathrm{~S}$ removal from syngas between the results obtained in this work and those presented in the literature.

Table 3. Comparative study on the efficiency of $\mathrm{H}_{2} \mathrm{~S}$ removal from syngas. Values were obtained in the best operation conditions. 


\section{Conclusions}

The influence of calcination temperature on the characteristics of the $\mathrm{ZnO}-\mathrm{TiO}_{2}$ composites was studied in this work through mineralogical, morphological, structural and textural analysis. From the phase composition standpoint, the results derived from both mineralogical and structural analyzes highlighted that with the increase of calcination temperature the $\mathrm{ZnO}-\mathrm{TiO}_{2}$ system evolves from an exclusively oxide system (calcination temperature of $500^{\circ} \mathrm{C}$ ) to a composite system consisting mainly of zinc orthotitanate (calcination temperature of $700^{\circ} \mathrm{C}$ ). The morphological analysis of the synthesized composites showed that as the calcination temperature increases, their component particles undergo a series of dimensional and shape changes that are closely related to the crystalline transformations of the oxide system and to the newly formed zinc titanate types. At high calcination temperatures (700-800 ${ }^{\circ} \mathrm{C}$ ) the zinc titanates formed sintering leading to a compact structure of the synthesized composites. The textural analysis revealed the formation of a predominantly non-porous composites, the pore volume and their surface area decreasing with the increasing of calcination temperature.

Therefore, it was found that ZT-700 type composites, which contain predominantly zinc orthotitanate, meets the characteristics that recommend it to be successfully used for the desulfurization of the syngas. In this regard, the tests carried out to establish the sulfur removal capacity of ZT-700 from a simulated gas stream showed that a removal degree of about $97 \%$ can be reached, which open the way for further experiments with real syngas. Thus, given the need for power generation using advanced technologies, such as gas/turbine engines or solid fuel cells, it is necessary to reduce the $\mathrm{H}_{2} \mathrm{~S}$ content to acceptable levels, and the use of ZT-700 type composites is a solution to achieve this objective. Also, in future research, will be pursued a better optimization of $\mathrm{ZnO}: \mathrm{TiO}_{2}$ molar ratio so as to increase the operating performance of these composites and to analyze the possibility of elimination of $\mathrm{H}_{2} \mathrm{~S}$ and other types of gases.

Author Contributions: Conceptualization, V.P.; Data curation, A.M.D. and C.M.; Formal analysis, C.B.; Funding acquisition, S.C.; Investigation, D.D. and E.V.; Methodology, C.B. and Software, G.G. All authors have read and agreed to the published version of the manuscript.

Funding: This work was supported by the European Regional Development Fund through Competitiveness Operational Program 2014-2020, Priority axis 1, Project No. P_36_611, MySMIS code 107066, Innovative Technologies for Materials Quality Assurance in Health, Energy and Environmental-Center for Innovative Manufacturing Solutions of Smart Biomaterials and Biomedical Surfaces-INOVABIOMED.

Conflicts of Interest: The authors declare no conflict of interest.

\section{References}

1. Stolecka, K.; Rusin, A. Analysis of hazards related to syngas production and transport. Renew. Energy 2020, 146, 2535-2555. [CrossRef]

2. Bassani, A.; Pirola, C.; Maggio, E.; Pettinau, A.; Frau, C.; Bozzano, G.; Pierucci, S.; Ranzi, E.; Manenti, F. Acid Gas to Syngas (AG2S ${ }^{\mathrm{TM}}$ ) technology applied to solid fuel gasification: Cutting $\mathrm{H}_{2} \mathrm{~S}$ and $\mathrm{CO}_{2}$ emissions by improving syngas production. Appl. Energy 2016, 184, 1284-1291. [CrossRef]

3. Motta, I.L.; Miranda, N.T.; Filho, R.M.; Marciel, M.R.W. Biomass gasification in fluidized beds: A review of biomass moisture content and operating pressure effects. Renew. Sust. Energ. Rev. 2018, 94, 998-1023. [CrossRef]

4. Cao, L.; Yu, I.K.M.; Xiong, X.; Tsang, D.C.W.; Zhang, S.; Clark, J.H.; Hu, C.; Ng, Y.H.; Shang, J.; Ok, Y.S. Biorenewable hydrogen production through biomass gasification: A review and future prospects. Environ. Res. 2020, 186, 109547. [CrossRef] [PubMed]

5. Wilson, S.M.V.; Tezel, F.H.; Kennedy, D.A. Adsorbent screening for $\mathrm{CO}_{2} / \mathrm{CO}$ separation for applications in syngas production. Sep. Purif. Technol. 2019. [CrossRef]

6. Minutillo, M.; Perna, A.; Jannelli, E.; Cigolotti, V.; Nam, S.W.; Yoon, S.P.; Kwon, B.W. Coupling of biomass gasification and SOFC - Gas Turbine Hybrid System for small scale cogeneration applications. Energy Procedia 2017, 105, 730-737. [CrossRef] 
7. Moradi, R.; Marcantonio, V.; Cioccolanti, L.; Bocci, E. Integrating biomass gasification with a steam-injected micro gas turbine and an Organic Rankine Cycle unit for combined heat and power production. Energy Convers. Manag. 2020, 205, 112464. [CrossRef]

8. Pala, L.P.R.; Wang, Q.; Kolb, G.; Hessel, V. Steam gasification of biomass with subsequent syngas adjustment using shift reaction for syngas production: An Aspen Plus model. Renew. Energy 2017, 101, 484-492. [CrossRef]

9. Moon, J.; Jo, W.; Jeong, S.; Bang, B.; Choi, Y.; Hwang, J.; Lee, U. Gas cleaning with molten tin for hydrogen sulfide and tar in producer gas generated from biomass gasification. Fuel 2017, 130, 318-326. [CrossRef]

10. Abdoulmoumine, N.; Adhikari, S.; Kulkarni, A.; Chattanathan, S. A review on biomass gasification syngas cleanup. Appl. Energy 2015, 155, 294-307. [CrossRef]

11. Cecilia, J.A.; Soriano, M.D.; Natoli, A.; Rodríguez-Castellón, E.; Nieto, J.M.L. Selective oxidation of hydrogen sulfide to sulfur using vanadium oxide supported on porous clay heterostructures (PCHs) formed by pillars silica, silica-zirconia or silica-titania. Materials 2018, 11, 1562. [CrossRef] [PubMed]

12. Frilund, C.; Simell, P.; Kaisalo, N.; Kurkela, E.; Koskinen-Soivi, M.-L. Desulfurization of biomass syngas using ZnO-based adsorbents: Long-term hydrogen sulfide breakthrough experiments. Energ. Fuel 2020. [CrossRef] [PubMed]

13. Marcantonio, V.; Bocci, E.; Ouweltjes, J.P.; Zotto, L.D.; Monarca, D. Evaluation of sorbents for high temperature removal of tars, hydrogen sulphide, hydrogen chloride and ammonia from biomass-derived syngas by using Aspen Plus. Int. J. Hydrogen Energy 2020, 45, 6651-6662. [CrossRef]

14. Kailasa, S.K.; Koduru, J.R.; Vikrant, K.; Tsang, Y.F.; Singhal, R.K.; Hussain, C.M.; Kim, K.-H. Recent progress on solution and materials chemistry for the removal of hydrogen sulfide from various gas plants. J. Mol. Liq. 2020, 297, 111886. [CrossRef]

15. Tuna, Ö.; Simsek, E.B.; Sarığlan, A.; DurakÇetin, Y. Influence of the process conditions on the kinetic behaviour of zinc orthotitanate for syngasclean-up. Biomass Bioenerg. 2019, 128, 105326. [CrossRef]

16. Macedo, K.R.M.; Oliveira, G.A.C.; Pereira, K.A.B.; Mendes, L.C.; Araújo, A.S.; Cassella, R.J. Titanium-zinc polycitrate precursor: Influence of thermal treatment on structural, thermal, optical characteristics of zinc titanates. Mater. Chem. Phys. 2019, 236, 121768. [CrossRef]

17. Budigi, L.; Nasina, M.R.; Shaik, K.; Amaravadi, S. Structural and optical properties of zinc titanates synthesized by precipitation method. J. Chem. Sci. 2015, 127, 509-518. [CrossRef]

18. Untea, I.; Dancila, M.; Vasile, E.; Belcu, M. Structural, morphological and textural modifications of $\mathrm{ZnO}-\mathrm{TiO}_{2}$ HTGD based sorbents induced by $\mathrm{Al}_{2} \mathrm{O}_{3}$ addition, thermal treatment and sulfurizing process. Powder Technol. 2009, 191, 27-33. [CrossRef]

19. Kubiak, A.; Siwińska-Ciesielczyk, K.; Jesionowski, T. Titania-based hybrid materials with $\mathrm{ZnO}, \mathrm{ZrO}_{2}$ and $\mathrm{MoS}_{2}$ : A review. Materials 2018, 11, 2295. [CrossRef]

20. Ayed, S.; Abdelkefi, H.; Khemakhem, H.; Matoussi, A. Solid state synthesis and structural characterization of zinc titanates. J. Alloys Compd. 2016, 677, 185-189. [CrossRef]

21. Chaves, A.C.; Lima, S.J.G.; Araújo, R.C.M.U.; Maurera, M.A.M.A.; Longo, E.; Pizani, P.S.; Simões, L.G.P.; Soledade, L.E.B.; Souza, A.G.; dos Santos, I.M.G. Photoluminescence in disordered $\mathrm{Zn}_{2} \mathrm{TiO}_{4}$. J. Solid State Chem. 2006, 179, 985-992. [CrossRef]

22. Arin, J.; Thongtem, S.; Phuruangrat, A.; Thongtem, T. Template synthesis of $\mathrm{Zn}_{2} \mathrm{TiO}_{4}$ and $\mathrm{Zn}_{2} \mathrm{Ti}_{3} \mathrm{O}_{8}$ nanorods by hydrothermal calcination combined processes. Mater. Lett. 2017, 193, 270-273. [CrossRef]

23. Fu, L.; Zhu, J.; Huang, W.; Fang, J.; Sun, X.; Wang, X.; Liao, K. Preparation of Nano-Porous Carbon-Silica Composites and Its Adsorption Capacity to Volatile Organic Compounds. Processes 2020, 8, 372. [CrossRef]

24. Chai, Y.-L.; Chang, Y.-S.; Chen, G.-J.; Hsiao, Y.-J. The effects of heat-treatment on the structure evolution and crystallinity of $\mathrm{ZnTiO}_{3}$ nano-crystals prepared by Pechini process. Mater. Res. Bull. 2008, 43, 1066-1073. [CrossRef]

25. Li, X.; Huang, W.; Liu, X.; Bian, H. Graphene oxide assisted ZIF-90 composites with enhanced n-hexane vapor adsorption capacity, efficiency and rate. J. Solid State Chem. 2019, 278, 120-890. [CrossRef]

26. Brito, L.; Almenglo, F.; Martín Ramírez, M.; Cantero, D. Feedback and Feedforward Control of a Biotrickling Filter for $\mathrm{H}_{2} \mathrm{~S}$ Desulfurization with Nitrite as Electron Acceptor. Appl. Sci. 2019, 9, 2669. [CrossRef]

27. Kubiak, A.; Siwińska-Ciesielczyk, K.; Bielan, Z.; Zielińska-Jurek, A.; Jesionowski, T. Synthesis of highly crystalline photocatalysts based on $\mathrm{TiO}_{2}$ and $\mathrm{ZnO}$ for the degradation of organic impurities under visible-light irradiation. Adsorption 2019, 25, 309-325. [CrossRef] 
28. Nethi, S.K.; Anand, P.N.A.; Rico-Oller, B.; Rodríguez-Diéguez, A.; Gómez-Ruiz, S.; Patra, C.R. Design, synthesis and characterization of doped-titanium oxide nanomaterials with environmental and angiogenic applications. Sci. Total Environ. 2017, 599-600, 1263-1274. [CrossRef]

29. Pinto, F.; André, R.N.; Franco, C.; Lopes, H.; Carolino, C.; Costa, R.; Gulyurtlu, I. Co-gasification of coal and wastes in a pilot-scale installation. 2: Effect of catalysts in syngas treatment to achieve sulphur and nitrogen compounds abatement. Fuel 2010, 89, 3340-3351. [CrossRef]

30. Bu, X.; Ying, Y.; Ji, X.; Zhang, C.; Peng, W. New development of zinc-based sorbents for hot gas desulfurization. Fuel Process. Technol. 2007, 88, 143-147. [CrossRef]

31. Zhang, L.; Liu, X.; Mu, X.; Li, Y.; Fang, K. Highly selective conversion of $\mathrm{H}_{2} \mathrm{~S}-\mathrm{CO}_{2}$ to syngas by combination of nonthermal plasma and $\mathrm{MoS}_{2} / \mathrm{Al}_{2} \mathrm{O}_{3}$. J. $\mathrm{CO}_{2}$ Util. 2020, 37, 45-54.

32. Chomiak, M.; Trawczyński, J.; Blok, Z.; Babiński, P. Monolithic Zn-Co-Ti based sorbents for hot syngas desulfurization. Fuel Process. Technol. 2016, 144, 64-70. [CrossRef]

(C) 2020 by the authors. Licensee MDPI, Basel, Switzerland. This article is an open access article distributed under the terms and conditions of the Creative Commons Attribution (CC BY) license (http://creativecommons.org/licenses/by/4.0/). 